\title{
Prenatal diagnosis and in utero treatment of severe congenital toxoplasmosis: a case report
}

\author{
Chusana Petpichetchian, Thitima Suntharasaj, Ounjai Kor-Anantakul \\ Maternal and Fetal Medicine Unit, Department of Obstetrics and Gynecology, Faculty of Medicine, \\ Prince of Songkla University, Songkhla 90110, Thailand
}

\begin{abstract}
Background: Acute infection of pregnant women with Toxoplasma gondii can result in fetal transmission. When clinical abnormalities are evident by ultrasonography in late gestation, medical treatment may be attempted, but the data on outcomes are limited.

Objectives: To present a case of congenital fetal toxoplasmosis from Thailand and review the literature.

Methods: A woman presented at 31 weeks of gestation with severe bilateral ventriculomegaly, cardiomegaly, hepatosplenomegaly with intrahepatic hyperechogenicities, and polyhydramnios. Medical treatment with pyrimethamine, sulfadiazine and folinic acid was initiated. There was no improvement. Social, medical, ethical and legal issues were considered.

Results: Delivery was indicated at $34^{+2}$ weeks of gestation because of premature amniorrhexis. The neonate suffered from respiratory distress, meningitis, ventilator-associated pneumonia, and expired at age 11 days.

Conclusions: When fetal congenital toxoplasmosis is diagnosed late in pregnancy with severe ultrasonographic abnormalities, the neonatal outcome is poor despite in utero treatment with antibiotics.
\end{abstract}

Keywords: Congenital infection, congenital toxoplasmosis, prenatal diagnosis, social and ethical considerations, therapy of fetus, ultrasonography

Toxoplasmosis is caused by the parasite Toxoplasma gondii. Acute infection in pregnant women can result in vertical transmission to the fetus, causing multiple sequelae that can present during the prenatal and neonatal period [1]. In France and Germany, routine screening is performed in pregnant women to detect seroconversion for $T$. gondii antibodies [2]. In such circumstances, fetal infection is usually detected and treatment administered before ultrasonographic abnormalities develop. The majority of fetuses (98.4\%) are then delivered without clinical symptoms of infection [3].

Mothers are not universally screened in other countries [2, 4]. Infected fetuses are then often diagnosed once clinical abnormalities are detected on routine ultrasonography. Therapeutic termination of pregnancy may be offered if the diagnosis is made before fetal viability. However, when the fetus is diagnosed during late gestation, counseling becomes challenging, as prognosis is poor. Yet data on outcomes following in utero treatment of clinically-affected fetuses remains limited. We report a case of severe congenital toxoplasmosis diagnosed in late pregnancy.

Correspondence to: Chusana Petpichetchian, Department of Obstetrics and Gynecology, Songklanagarind Hospital, Hat Yai, Songkhla 90110, Thailand.E-mail: pchusana@medicine.psu.ac.th
The report of this case was approved by the Human Research Ethics Committee, Faculty of Medicine Prince Songkla University (Rec No. 57-28212-1). The patient provided written informed consent for this publication.

\section{Case report}

A 41 -year-old Thai gravida 3 , parity 2 , at $31^{+1}$ weeks of gestation, was referred for evaluation of abnormal cerebral ultrasound findings in her fetus. Her previous pregnancy history, antenatal history, and ultrasonographic findings at 17 weeks of gestation for amniocentesis were unremarkable. The fetal chromosomal study was normal. She did not own a cat, but had been feeding a stray cat near her home. She had never been screened for T. gondii antibodies.

Ultrasonography at $31^{+1}$ weeks of gestation revealed severe bilateral ventriculomegaly with areas of hyperechogenicities in the periventricular region (Figure1), cardiomegaly, hepatosplenomegaly with intrahepatic hyperechogenicites (Figure 2), and polyhydramnios. Fetal congenital infection was suspected and fetal blood sampling was performed and sent for serologic testing. The result was positive for $T$. gondii $\operatorname{IgG}$ and $\operatorname{IgM}$ antibodies. 


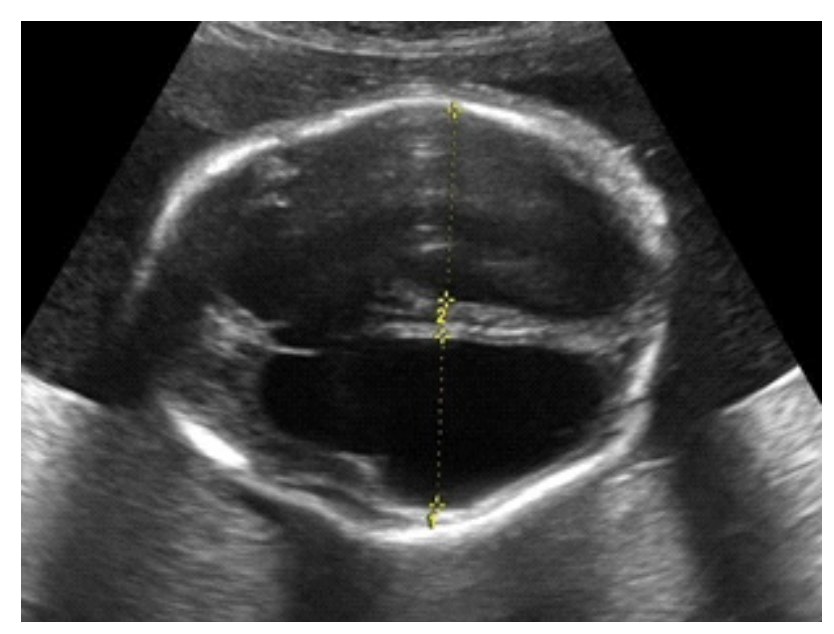

Figure 1. Ultrasound image. Transventricular view of the fetal head shows severe dilatation of lateral ventricles with thinning of the cerebral cortex and periventricular calcification. The lateral ventricle measures $35.9 \mathrm{~mm}$.

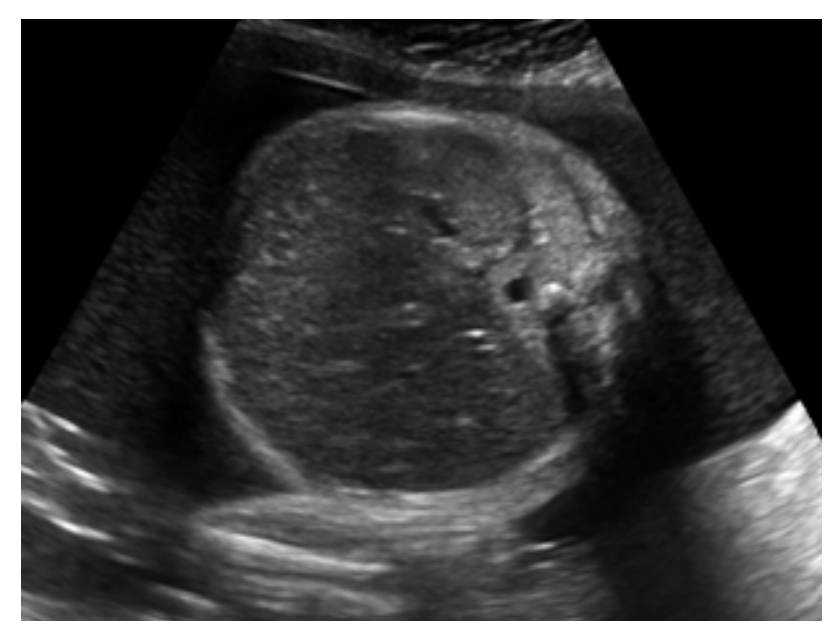

Figure 2. Ultrasound image. Cross-sectional view of the fetal abdomen shows liver enlargement with diffuse intrahepatic calcifications

After counseling, the patient was started with written informed consent on pyrimethamine, sulfadiazine and folinic acid (PSF regimen) at $32^{+1}$ weeks of gestation. No adverse effects related to the medications were observed during the treatment period. Ultrasonography was repeated at $34^{+2}$ weeks of gestation and showed similar findings. On the same day, she developed premature amniorrhexis and went into labor.

The fetus was delivered by cesarean section because of previous section. The female neonate weighed $1,920 \mathrm{~g}$, which was appropriate for her gestational age. The Apgar scores at 1 and 5 minutes were 7 and 8 , respectively. She was intubated because of respiratory distress, which later was diagnosed as congenital pneumonia and respiratory distress syndrome. An initial examination revealed a normal head circumference of $30 \mathrm{~cm}$, jaundice, and hepatosplenomegaly. An eye examination showed iris atrophy and vitreous haziness compatible with toxoplasmosis. The IgG test was positive in serum and cerebrospinal fluid. The placental showed chronic villitis with calcifications and encysted organisms in trophoblastic cells (Figure 3), findings compatible with toxoplasmosis.

The PSF regimen was given to the newborn. Despite this treatment, her clinical course was complicated with neonatal sepsis, meningitis and ventilator-associated pneumonia. Death occurred at the age of 11 days. 


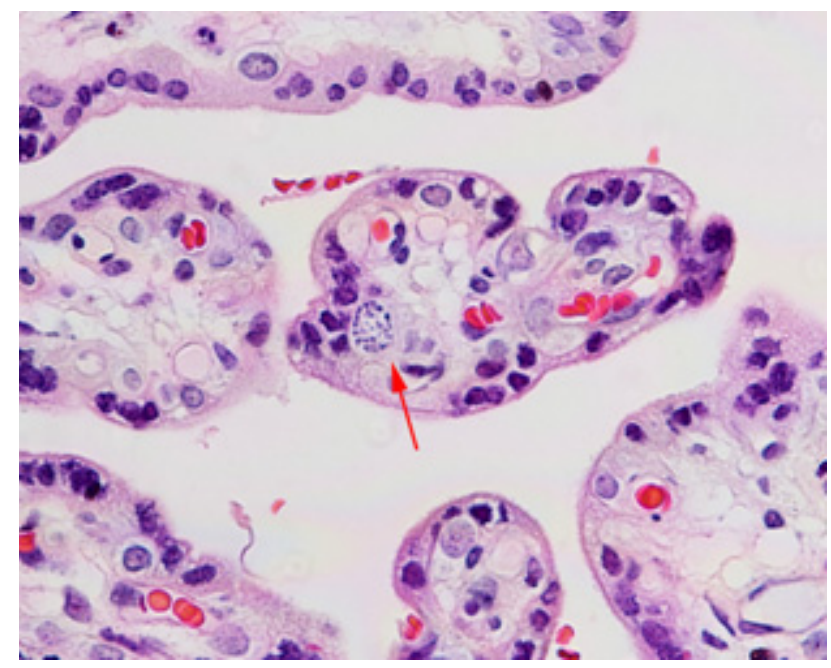

Figure 3. Pathological image. Encysted organisms in the trophoblastic cells of the placenta (red arrow), hematoxylin and eosin stain. The size of the parasites can be estimated from the erythrocytes (approximately $7 \mu \mathrm{m}$ diameter).

\section{Discussion}

We report a case of congenital toxoplasmosis diagnosed at late gestation when the fetus demonstrated multiple abnormalities on ultrasonography including ventriculomegaly, periventricular calcifications, cardiomegaly, hepatosplenomegaly with intrahepatic hyperechogenicities, and polyhydramnios.

Humans are usually infected via eating undercooked infected meat, or ingesting food contaminated with toxoplasma oocysts. The seroprevalence of toxoplasmosis in women of a child-bearing age varies by geographical region, ranging from $0.8 \%$ in South Korea to $77 \%$ in Brazil [2]. In Thailand, $19 \%-28.3 \%$ of pregnant women have been found to be seropositive for $T$. gondii antibodies $[5,6]$.

When pregnant women become infected with T. gondii, most remain asymptomatic, yet parasites can be transmitted to their fetus across the placenta. Risk depends on timing of infection and is estimated to be $10 \%-25 \%$ in the first trimester and increases to $60 \%-90 \%$ in the third trimester. Conversely, clinical manifestations are more severe the earlier the infection occurs [1]. Ultrasonographic findings include hydrops, ventricular dilatation, intracranial calcifications, intrahepatic calcifications, pleural effusion, pericardial effusion, and a thick, echogenic placenta. Abnormal intracranial findings indicate severe fetal infection and a poor prognosis [7]. Fetal infection is usually diagnosed by fetal blood sampling for antibody detection or amniotic fluid polymerase chain reaction (PCR).

When the fetuses are severely affected, therapeutic termination of pregnancy is usually offered
$[8,9]$. According to the International Federation of Gynecology and Obstetrics (FIGO), when termination of pregnancy following prenatal diagnosis is performed beyond 22 weeks of gestation, it must be preceded by feticide to ensure delivery of a stillborn fetus [10].

In Thailand, abortion is legal if performed by a physician to protect the health of the mother and in pregnancy that resulted from sexual crimes. Pregnancy termination, when severe fetal anomalies are diagnosed, and in order to preserve the mothers' mental health is acceptable according to new medical legislation published in the Royal Thai Government Gazette [11]. However, for nonlethal anomalies, pregnancy termination is possible only before the pregnancy reaches the threshold of viability, usually before 22 to 24 weeks of gestation, depending on the institution. Feticide for fetal anomaly is not acceptable in Thailand and termination of pregnancy at late gestation for nonlethal anomaly is considered inappropriate because the fetus may be born alive and suffer additional complications from prematurity.

In the present case, the gestational age of the fetus at diagnosis was beyond the threshold of viability and the abnormalities found were nonlethal. These ethical and legal limitations were discussed with the patient and invasive fetal testing was recommended only to confirm the diagnosis and to guide whether further fetal treatment can be offered.

After the diagnosis of congenital toxoplasmosis was confirmed, the patient and her husband were informed about the results and that the fetus carried the risk of stillbirth and severe neurological deficits if she survived. Despite the poor prognosis, and after 
discussion with parents, we decided to administer antibiotics in the hope of minimizing morbidity. This management was based on few reported cases of clinically-affected fetuses that were treated. Two cases in 2005 and 2011 involved severely-affected fetuses, who had residual abnormalities in postnatal life despite treatment in utero $[12,13]$. However, Friedman, reported a case in 1999, of fetal hydrops caused by congenital toxoplasmosis, in which the fetus showed improvement after the initiation of the PSF regimen, and the neonate had only minimal abnormalities in postnatal life [14]. A large retrospective analysis from Germany in 2010, also indicated effectiveness of prenatal treatment of toxoplasmosis, even in fetuses with abnormal prenatal findings [3]. In that study, there were 3 cases of prenatally-diagnosed fetal ventriculomegaly; all of them experienced disease improvement, as evidenced via either subsequent prenatal ultrasonography or other postnatal imaging. The authors postulated that if the treatment was initiated as early as possible (not later than 12 weeks following maternal infection) it could be beneficial. The details of each case are summarized in Table 1.

For the present case, the duration of maternal infection could not be determined because the mother was asymptomatic and no $T$. gondii screening was conducted before presentation. The patient received only 2 weeks of medications before delivery. The poor perinatal outcome resulted not only from the toxoplasmosis infection, but also from the preterm delivery and superimposed complications of prematurity, such as respiratory distress syndrome. However, multiple clinical manifestations of congenital toxoplasmosis were demonstrated in the newborn and in the placental histology, indicating poor response to prenatal medical therapy. We conclude that late detection of the infection, severe clinical manifestations in the fetus, late treatment, and the short duration of treatment-to-delivery time contributed to the poor outcome.

\section{Conclusion}

From our experience, when fetal congenital toxoplasmosis is diagnosed late in pregnancy with severe ultrasonographic abnormalities, the neonatal outcome is likely to be poor despite in utero treatment with antibiotics. Premature delivery and short treatment duration may worsen the prognosis for the fetus.

Table 1. Clinical summary of patients with prenatal findings of congenital toxoplasmosis described in the literature and our patient

\begin{tabular}{|c|c|c|c|c|c|c|c|}
\hline Author (year) & $\begin{array}{l}\text { Gestational } \\
\text { age (GA) at } \\
\text { diagnosis }\end{array}$ & $\begin{array}{l}\text { Diagnostic } \\
\text { methods }\end{array}$ & $\begin{array}{l}\text { GA at } \\
\text { treatment }\end{array}$ & $\begin{array}{l}\text { Age at } \\
\text { delivery }\end{array}$ & Treatment & Prenatal findings & Postnatal outcomes \\
\hline $\begin{array}{l}\text { Friedman et al. } \\
1999[14]\end{array}$ & 27 weeks & $\begin{array}{l}\text { IgM, } \\
\text { polymerase } \\
\text { chain } \\
\text { reaction } \\
\text { (PCR) }\end{array}$ & 28 weeks & 39 weeks & $\begin{array}{l}\text { Pyrimethamine, } \\
\text { sulfadiazine, and } \\
\text { folinic acid } \\
\text { (PSF) }\end{array}$ & $\begin{array}{l}\text { Ventriculomegaly } \\
\text { Ascites } \\
\text { Pleural effusion } \\
\text { Pericardial effusion }\end{array}$ & $\begin{array}{l}\text { Chorioretinitis } \\
\text { Periventricular } \\
\text { calcification } \\
\text { Normal development } \\
\text { at } 4 \text { months }\end{array}$ \\
\hline $\begin{array}{l}\text { Nowokowska } \\
\text { et al. } 2005 \\
{[12] 20052005}\end{array}$ & 27 weeks & $\begin{array}{l}\text { IgG, IgM, } \\
\text { IgG } \\
\text { avidity, } \\
\text { PCR }\end{array}$ & 28 weeks & 38 weeks & $\begin{array}{l}\text { Spiramycin then } \\
\text { PSF } \\
\text { Shunt placement } \\
\text { at } 35 \mathrm{wks}\end{array}$ & $\begin{array}{l}\text { Hydrocephalus } \\
\text { Clubfoot }\end{array}$ & $\begin{array}{l}\text { Hydrocephalus } \\
\text { Intracranial } \\
\text { calcifications } \\
\text { Seizure } \\
\text { Chorioretinitis } \\
\text { Alive }\end{array}$ \\
\hline $\begin{array}{l}\text { Tamaru et al. } \\
2011 \\
{[13] 012011}\end{array}$ & 23 weeks & $\operatorname{IgG}, \operatorname{IgM}$ & 25 weeks & 32 weeks & $\begin{array}{l}\text { Sulfadoxine, } \\
\text { pyrimethamine, } \\
\text { azithromycin, } \\
\text { acetylspiramycin }\end{array}$ & $\begin{array}{l}\text { Ventriculomegaly } \\
\text { Ascites } \\
\text { Pericardial effusion } \\
\text { Cardiomegaly } \\
\text { Placentomegaly }\end{array}$ & $\begin{array}{l}\text { Ventriculomegaly } \\
\text { Ascites } \\
\text { Hepatosplenomegaly } \\
\text { Chorioretinitis } \\
\text { Meningitis } \\
\text { Alive at } 7 \text { months }\end{array}$ \\
\hline Present case & 31 weeks & $\operatorname{IgG}, \operatorname{IgM}$ & 32 weeks & 34 weeks & PSF & $\begin{array}{l}\text { Ventriculomegaly } \\
\text { Cardiomegaly } \\
\text { Hepatosplenomegaly } \\
\text { Hydramnios }\end{array}$ & $\begin{array}{l}\text { Ventriculomegaly } \\
\text { Hepatosplenomegaly } \\
\text { Iris atrophy } \\
\text { Meningitis } \\
\text { Neonatal death }\end{array}$ \\
\hline
\end{tabular}




\section{Acknowledgments}

The authors would like to thank Assistant Professor Dr. Kanita Kayasut and Dr. Sittipong Wangsawibul from the Department of Pathology, Faculty of Medicine, Prince of Songkla University, Songkhla, Thailand for providing the pathological picture, Mr. Edmond Subashi from the International Affairs Office, Faculty of Medicine, Prince of Songkla University, Songkhla, Thailand, for editorial assistance. We also wish to thank our colleagues in the MaternalFetal Medicine Unit, the Neonatal Intensive Care Unit, Songklanagarind Hospital, Songkhla, Thailand, for their contribution in relation to this patient.

\section{Conflict of interest statement}

The authors declare that there is no conflict of interest in this research.

\section{References}

1. Jones J, Lopez A, Wilson M. Congenital toxoplasmosis. Am Fam Physician. 2003; 67:2131-8.

2. Pappas G, Roussos N, Falagas ME. Toxoplasmosis snapshots: global status of Toxoplasma gondii seroprevalence and implications for pregnancy and congenital toxoplasmosis. Int J Parasitol. 2009; 39: 1385-94.

3. Hotop A, Hlobil H, Gross U. Efficacy of rapid treatment initiation following primary Toxoplasma gondii infection during pregnancy. Clin Infect Dis. 2012; 54: 1545-52.

4. Chaudhry SA, Gad N, Koren G. Toxoplasmosis and pregnancy. Can Fam Physician. 2014; 60:334-6.

5. Tantivanich S, Amarapal P, Suphadtanaphongs W, Siripanth C, Sawatmongkonkun W. Prevalence of congenital cytomegalovirus and Toxoplasma antibodies in Thailand. Southeast Asian J Trop Med Pub Health. 2001; 32:466-9.
6. Nissapatorn V, Suwanrath C, Sawangjaroen N, Ling LY, Chandeying V. Toxoplasmosis-serological evidence and associated risk factors among pregnant women in southern Thailand. Am J Trop Med Hyg. 2011;85:243-7.

7. O'Boyle MK, Pretorius DH. Fetal infections. In: Nyberg DA MJ, Pretorius DH, Pilu G, editors. Diagnostic imaging of fetal anomalies. Philadelphia: Lippincott Williams \& Wilkins. 2003; 746-76.

8. Villena I, Bory JP, Chemla C, Hornoy P, Pinon JM. Congenital toxoplasmosis: necessity of clinical and ultrasound follow-up despite negative amniocentesis. Prenat Diagn. 2003; 23:1098-9.

9. Zivkovic T, Ivovic V, Vujanic M, Klun I, Bobic B, Nikolic A, et al. Adverse fetal outcome in the absence of timely prenatal diagnosis of congenital toxoplasmosis. Wien Klin Wochenschr. 2011; 123(Suppl 1):43-6.

10. FIGO Committee for the Ethical Aspects of Human Reproduction and Women's Health. Ethical aspects concerning termination of pregnancy following prenatal diagnosis. Int J Gynaecol Obstet. 2008; 102: 97-8.

11. Chaturachinda K. Unsafe abortion in Thailand: Roles of RTCOG. Thai J Obstet Gynaecol. 2014; 22:2-7.

12. Nowakowska D, Respondek-Liberska M, Golab E, Stray-Pedersen B, Szaflik K, Dzbenski TH, et al. Too late prenatal diagnosis of fetal toxoplasmosis: a case report. Fetal Diagn Ther. 2005; 20:190-3.

13. Tamaru S, Kikuchi A, Takagi K, Wakamatsu M, Horikoshi T, Ogiso Y. Fetal therapy of severe symptomatic toxoplasmosis using azithromycin. J Obstet Gynaecol Res. 2011; 37:953-7.

14. Friedman S, Ford-Jones LE, Toi A, Ryan G, Blaser S, Chitayat D. Congenital toxoplasmosis: prenatal diagnosis, treatment and postnatal outcome. Prenat Diagn. 1999; 19:330-3. 